\title{
Erratum
}

\section{Ovarian cancer in younger vs older women: a population-based analysis}

JK Chan, R Urban, MK Cheung, K Osann, JY Shin, A Husain, NN Teng, DS Kapp, JS Berek and GS Leiserowitz

British Journal of Cancer (2007) 96, I492. doi:I0.1038/sj.bjc.6603757 www.bjcancer.com

(c) 2007 Cancer Research UK

Correction to: British Journal of Cancer (2006) 95, 1314-1320. doi: 10.1038/6603457 (published Corrigendum, British Journal of Cancer (2007) 96, 534. doi: 10.1038/sj.bjc.6603601).
Owing to a publishing error, the revised author listing for the above paper was incorrectly ordered. JY Shin should have been added as the fifth, and not final, author - we are happy to correct this mistake. The complete and correct author listing is shown above. 